\title{
Synthesis of lactic acid from sugar palm trunk waste (Arenga pinnata): Preliminary hydrolysis and fermentation studies
}

\author{
WHINY HARDIYATI ERLIANA ${ }^{1}$, TRI WIDJAJA ${ }^{1, \boldsymbol{\nu}}$, ALI ALTWAY ${ }^{2}$, LILY PUDJIASTUTI $^{3}$ \\ ${ }^{1}$ Biochemical Technology Laboratory, Department of Chemical Engineering, Faculty of Industrial Technology, Institut Teknologi Sepuluh Nopember. \\ J1. Raya ITS, Sukolilo, Surabaya 60111, East Java, Indonesia. Tel. +62-31-5946240, `email: triw@chem-eng.its.ac.id \\ ${ }^{2}$ Heat and Mass Transport Laboratory, Department of Chemical Engineering, Faculty of Industrial Technology, Institut Teknologi Sepuluh Nopember. \\ Jl. Raya ITS, Sukolilo, Surabaya 60111, East Java, Indonesia \\ ${ }^{3}$ Department of Industrial Chemical Engineering, Faculty of Vocational Studies, Institut Teknologi Sepuluh Nopember. Jl. Raya ITS, Sukolilo, Surabaya \\ 60111, East Java, Indonesia
}

Manuscript received: 26 December 2019. Revision accepted: 29 April 2020.

\begin{abstract}
Erliana WH, Widjaja T, Altway A, Pudjiastuti L. 2020. Synthesis of lactic acid from sugar palm trunk waste (Arenga pinnata): Hydrolysis and fermentation studies. Biodiversitas 21: 2281-2288. The increasing problems of global energy and the environment are the main reasons for developing products with new techniques through green methods. Sugar palm trunk waste (SPTW) has potential as agricultural waste because of its abundant availability, but it is not used optimally. This study was aimed to determine the effect of various microorganisms on increasing lactic acid production by controlling $\mathrm{pH}$ and temperature conditions in the fermentation process. SPTW contains $43.88 \%$ cellulose, $7.24 \%$ hemicellulose, and $33.24 \%$ lignin. The lignin content in SPTW can inhibit reducing sugar formation; the pretreatment process should remove this content. In the study, the pretreatment process was conducted using acidorganosolv. In the acid pretreatment, $0.2 \mathrm{M} \mathrm{H}_{2} \mathrm{SO}_{4}$ was added at $120^{\circ} \mathrm{C}$ for 40 minutes; organosolv pretreatment using $30 \%$ ethanol (v/v) at $107^{\circ} \mathrm{C}$ for 33 minutes was able to increase cellulose content by $56.33 \%$ and decrease lignin content by $27.09 \%$. The pretreatment was followed by an enzymatic hydrolysis process with a combination of commercial cellulase enzymes from Aspergillus niger (AN) and Trichoderma reesei (TR), with variations of 0:1, 1:0, 1:1, 1:2 and 2:1. The best reducing sugar concentration was obtained with an AN: TR ratio of 1:2 to form reducing sugar from cellulose. Subsequently, lactic acid fermentation was carried out using lactic acid bacteria at $37^{\circ} \mathrm{C}$ and $\mathrm{pH} 6$ incubated for 48 hours. The highest lactic acid concentration $(33.292 \mathrm{~g} / \mathrm{L})$ was obtained using a mixed culture of Lactobacillus rhamnosus and Lactobacillus brevis to convert reducing sugar become lactic acid.
\end{abstract}

Keywords: Acid-organosolv pretreatment, cellulase enzyme, lactic acid, lactic acid bacteria, sugar palm trunk waste

\section{INTRODUCTION}

Lactic acid has many applications in the food, chemical, textile, pharmaceutical, and other industries. Recently, there has been great demand for it, as it can be used as a monomer for the production of biodegradable Poly Lactic Acid (PLA) polymers, which is an alternative synthetic polymer derived from petroleum resources. Only racemic DL-lactic acid is produced through chemical synthesis, while the desired stereoisomer (pure L-or D-lactic acid) can be optically produced through the production of renewable resource fermentation by selecting appropriate microorganisms for the fermentation of lactic acid (Alves et al. 2018).

Indonesia has a high potential for agricultural waste. The utilization of this waste can reduce the fears of competition for food usage in the production of lactic acid. Lignocellulosic biomass is the most promising raw material, given its availability and low cost. SPTW (Arenga pinnata) comes from plants containing starches and sugars which have the potential for lactic acid production. Until now, research on the production of lactic acid from the palm sugar waste industry has been lacking in information. According to research conducted by Sanyang et al. (2016), the ethanol yield of palm trees exceeds that of other raw materials which are often used, which shows the high cellulose content in SPTW. The composition of SPTW is $43.88 \%$ cellulose, $7.24 \%$ hemicellulose, $33.24 \%$ lignin, $1.01 \%$ ash, and $2.73 \%$ extractive (Ilyas et al. 2019).

Lactic acid $\left(\mathrm{C}_{3} \mathrm{H}_{6} \mathrm{O}_{3}\right)$ can be produced from three categories of agricultural raw materials, namely; simple sugars, starches, and lignocellulose. As a raw material for lignocellulose, the waste used in this research contained a high cellulose and lignin content, which must be delignified in order to optimize the work of the enzymes in degrading cellulose. In the experiment, the chemical pretreatment was conducted in two stages, using acid and organosolv solvents. When chemical pretreatment is expected to be able to produce substrates that are rich in cellulose (Andrić et al. 2010). The dissolved lignin becomes an inhibitor for the bacteria metabolism and increases conversion to reducing sugars by declining hemicellulose content (Mesa et al. 2010). Furthermore, it becomes eliminate dissolved phenolic components that can inhibit the activity of cellulase enzymes (Sun et al. 2002).

This was followed by the enzymatic hydrolysis process. The first step in cellulose hydrolysis is to increase the action of the enzymes into substrates by adsorption. Bound fractions, such as endoglucanase and exoglucanase, convert cellulose to cellobiose. It is at this stage that the cellulase 
enzyme from Trichoderma reesei needed. Unbonded fractions such as $\beta$-glucosidase then convert cellobiose to glucose with the cellulase enzyme from Aspergillus niger (Fenila and Yogendra 2016). The use of a combination of pure cellulase enzymes from $A$. niger and $T$. reesei is expected to be able to increase the hydrolytic enzymes and eliminate inhibitors such as cellobiose, xylose, and furfural from the pretreatment process. Selection of the right microorganisms for lactic acid fermentation can determine the yield obtained. According to Bushara et al. (2018), the mixed culture of microorganisms can increase the yield of lactic acid, which can be an opportunity to increase lactic acid production. The use of two microorganisms is considered very promising for the efficiency of the production of beneficial lactic acid and rapid conversion to lactic acid (Ismail et al. 2018). However, research into the production of lactic acid with waste from the palm flour industry as the raw material is lacking in detail. Some studies still use raw materials from the first generation, such as that conducted by Chaisu et al. (2014), who used molasses because they are considered to be raw materials with high potential for development, while there are still many raw materials from the second generation that have more potential.

Therefore, the purpose of this research was to investigate the effect of using a combination of pure cellulase enzymes from AN and TR with variations of $0: 1$, $1: 0,1: 1,1: 2$, and $2: 1$ in the production of lactic acid for polylactic acid (PLA) from fermented SPTW. The variations in single microorganism culture (Lactobacillus acidophilus, Lactobacillus brevis, Lactobacillus casei, and Lactobacillus rhamnosus) and mixed microorganism cultures (L. acidophilus and L. brevis; L. casei and $L$. brevis; L. rhamnosus and L. brevis) were also studied.

\section{MATERIALS AND METHODS}

\section{Microorganisms and inoculum preparation}

The lactic acid bacteria species (LAB) used in this study were Lactobacillus acidophilus, Lactobacillus brevis, Lactobacillus casei, and Lactobacillus rhamnosus, which were obtained from microbiology laboratory, Department of Biology, Airlangga University, Surabaya. One loop of each microbe was inoculated to $50 \mathrm{~mL}$ of sterilized MRS broth and incubated for $48 \mathrm{~h}$ at $37^{\circ} \mathrm{C}$. The counting chamber analysis method was used to find the log phase of the microorganisms.

\section{Preparation of sugar palm trunk waste (SPTW)}

SPTW was obtained from Tasikmalaya, West Jawa, Indonesia. It was sun-dried for three days and then mashed using a grinding machine and sieved to a size of 120 mesh. The smaller substrate particles help the pretreatment and hydrolysis process by increasing the contact surface between the substrate and the enzymes, and the lignocellulose content naturally degraded. Before usage, the SPTW was oven-dried at $60^{\circ} \mathrm{C}$ to remove moisture content.

\section{Acid-organosolv pretreatment process}

The acid-organosolv pretreatment process was used to remove lignin content. The first stage of pretreatment used an acid solvent, namely $\mathrm{H}_{2} \mathrm{SO}_{4}$. The use of acid solvents aimed to increase the efficiency of the organosolv process by suppressing the formation of furfural caused by hemicellulose degradation. Cellulose is a crystalline that is more resistant to acids than hemicellulose, whereas hemicellulose has a random amorphous structure with complex chemical composition and is easily hydrolyzed into glucose. In the acid pretreatment, the SPTW was prepared by weighing $100 \mathrm{~g}$ of it and placing it into an Erlenmeyer flask. $0.2 \mathrm{M} \mathrm{H}_{2} \mathrm{SO}_{4}$ was then added, with a solid to liquid ratio of $1: 5(\mathrm{w} / \mathrm{w})$, then heated at $120^{\circ} \mathrm{C}$ using an autoclave for 40 minutes. Sulfuric acid is the most commonly used chemical pretreatment for lignocellulosic biomass in acid pretreatment. For the second stage, the organosolv pretreatment was conducted using acid-treated SPTW with $30 \%$ (v/v) ethanol and 3\% (w/w) $\mathrm{NaOH}$ added as a catalyst, with a solid to liquid ratio of 1:7 (w/w), and heated at $107^{\circ} \mathrm{C}$ for 33 minutes by autoclave. The use of ethanol as an organic solvent in the second pretreatment process stage is because it is a renewable solvent that is capable of producing higher recovery solids, protecting cellulosic fractions, increasing the porosity of residual solids, and recovering high-quality lignin fractions with potential use in several industrial applications (Wildschut et al. 2013). The solid residue was separated by filtration and washed with aquadest until it reached neutral $\mathrm{pH}$ and was then oven-dried at $60^{\circ} \mathrm{C}$.

\section{Enzymatic hydrolysis}

The enzymes used in this study were pure cellulase enzymes isolated from $A$. niger and $T$. reesei. A glucose standard curve was prepared to indicate the cellulase enzyme activity. From the absorbance obtained, a calibration curve was produced between absorbance and glucose concentration, so that a standard glucose curve could be obtained to test the activity of the cellulase enzymes. Enzyme activity was tested by the DNS method and absorbance measurement with a wavelength of 540 $\mathrm{nm}$.

One-Unit (IU) of enzyme activity is defined as the amount of enzyme needed to produce one $\mu$ mol of reducing sugar per minute. The enzymatic hydrolysis process, with a varying mixture of cellulase enzymes from $A$. niger and $T$. reese $i$ was used to compare the effect of the variation of the mixture of cellulase enzymes with AN:TR combinations of $0: 1,1: 0,1: 1,1: 2$ and $2: 1$. The operating conditions of the hydrolysis process were at the temperature of $60^{\circ} \mathrm{C}$ and $\mathrm{pH}$ of 5.5, over a period of 48 hours. The temperature of $60^{\circ} \mathrm{C}$ was kept constant by using a $125 \mathrm{rpm}$ incubator shaker. In this SPTW hydrolysis what needs to be prepared first is the glucose standard curve, which serves to test the glucose concentration during the hydrolysis process. Analysis of glucose concentrations in hydrolyzate by the DNS method was conducted on each sample at any given time interval. Samples were taken with a dropper pipette, and put into a centrifuged tube for 10 minutes at a speed of $10,000 \mathrm{rpm}$ at a temperature of $4^{\circ} \mathrm{C}$ on a centrifuge. This aimed to 
separate the solids and liquids from the hydrolyzate because centrifugation (liquid) results are needed for analysis by the DNS method. $0.2 \mathrm{~mL}$ of the solution for each centrifugation sample was added with $1.8 \mathrm{~mL}$ of aquadest and $3 \mathrm{~mL}$ of DNS, then vortexed so that the solution became homogeneous. Subsequently, the solution was heated in boiling water for 10 minutes, cooled in ice water for 10 minutes, and then allowed to stand in room temperature water for 10 minutes.

\section{Lactic acid fermentation}

Each single bacterial culture of microorganisms (Lactobacillus acidophilus, L. casei, L.brevis, and L. rhamnosus) and mixed microorganism cultures ( $L$. acidophilus and L. brevis; L. casei and L. brevis and $L$. rhamnosus and L. brevis) and a loopful of cells from agar slant that had been inoculated were implanted into the starter solution. Each starter solution was then incubated at $37^{\circ} \mathrm{C}$ in the Erlenmeyer flask (Panesar et al. 2010).

Starters are made using a MRS broth medium, which has been inoculated with bacteria and incubated during the log phase of each variable. The substrate then used in the fermentation process is the hydrolyzate from the sugar palm pulp, which has been hydrolyzed and separated from its sediment. $10 \mathrm{~g} / \mathrm{L}$ of nutritional supplementation in the form of ammonium sulfate is then added together with 2.5 $\mathrm{g} / \mathrm{L}$ yeast extract. A 1:4 comparison between the yeast extract and ammonium sulfate was made as per Nancib (2001), this comparison gives almost the same performance as the use of $20 \mathrm{~g} / \mathrm{L}$ yeast extract. This can reduce the cost of using nitrogen sources by $80 \%$ (Nancib 2001). The medium for the lactic acid fermentation process consisted of hydrolyzed pretreated SPTW enriched with yeast extract, with $\mathrm{CaCO}_{3}$ added for buffering. The medium was autoclaved at $121^{\circ} \mathrm{C}$ for $15 \mathrm{~min}$. $\mathrm{MnSO}_{4} \cdot \mathrm{H}_{2} \mathrm{O}(0.05 \mathrm{~g} / \mathrm{L})$, $\mathrm{MgSO}_{4} .7 \mathrm{H}_{2} \mathrm{O}(0.2 \mathrm{~g} / \mathrm{L})$ and $\mathrm{KH}_{2} \mathrm{PO}_{4}(0.5 \mathrm{~g} / \mathrm{L})$ were used. The ions in salt are constituents of the enzyme lactate dehydrogenase, which functions to catalyze the conversion of pyruvate to lactate at the end of the glycolysis process (Buyukkileci and Harsa 2004). The $\mathrm{pH}$ was then adjusted according to the variable, using $1.5 \mathrm{M}$ citric acid and $4 \mathrm{M}$ $\mathrm{NaOH} . \mathrm{CaCO}_{3}$ was added as a neutralizing agent to maintain the $\mathrm{pH}$ during the fermentation process. $\mathrm{CaCO}_{3}$ was chosen because it is in the form of a solid, which made it easier to separate the lactic acid at the end of the fermentation process. The Erlenmeyer flask, which contained the fermentation media, was then sterilized using an autoclave at $121^{\circ} \mathrm{C}$ for 15 minutes. The starter was added to the fermentation medium at $10 \%$ of its volume (Coelho et al. 2010). The inoculated flask was incubated at various temperatures, with a shaking speed of $125 \mathrm{rpm}$, for 48 hours. A sample was taken every 8 hours.

\section{Analysis}

TAPPI Test Method T222 was used to analyze the lignin content, and the Designer Energy Method of Loelovich (2015) was employed to determine the cellulose and hemicellulose content. Thermal Gravimetric Analysis (TGA) is used to determine the composition of moisture, cellulose, hemicellulose, lignin, and ash in raw materials
Table 1. Temperature range for determining chemical composition with TGA (Wijaya et al. 2017)

\begin{tabular}{ll}
\hline Component & Range temperature $\left({ }^{\circ} \mathbf{C}\right)$ \\
\hline Moisture & $0-200$ \\
Hemicellulose & $200-300$ \\
Cellulose & $300-360$ \\
Lignin & $360-500$ \\
Ash & $>500$ \\
\hline
\end{tabular}

(Table 1). This analysis was conducted using a Perkin Elmer Diamond TG/DTA thermal analyzer, with a heating and cooling rate of $10^{\circ} \mathrm{C} / \mathrm{min}$ in a continuous flow of nitrogen gas of $150 \mathrm{~mL} / \mathrm{min}$. Determination of this composition was made by analyzing the thermal stability of the sample. This analysis produced a TGA curve, which showed a decrease in material mass percentage by heating temperature.

The X-Ray Diffraction Analysis was performed on the SPTW before and after the pretreatment, with the help of a PANalytical X-pert Pro Diffractometer (Material-ITS Engineering). The scope scan was set at $2 \theta=5^{\circ}-50^{\circ}$. Calculation of the crystalline index value using the XRD peak height method has been widely used in previous studies (Park et al. 2010). The value of the Crystallinity Index (CrI) was calculated using the following eq. (1):

$$
\mathrm{CrI}=\left(\mathrm{I}_{002}-\mathrm{I}_{\mathrm{am}}\right) / \mathrm{I}_{002} \times 100 \%
$$

Where: $\mathrm{I}_{002}$ is the crystalline cellulose fraction at maximum diffraction peak intensity of $2 \theta=22.5^{\circ}$ and $I_{a m}$ is the amorphous cellulose fraction at a minimum diffraction peak intensity of $2 \theta=18.7^{\circ}$

The X-Ray diffraction method was used to find the value of the Crystallinity Index of the lignocellulosic material. XRD will read the Crystallinity Index value of cellulose crystals in the solid sample. The intensity of amorphous cellulose can be seen at a $2 \theta$ angle of approximately $18^{\circ}$ and crystalline cellulose at $22-24^{\circ}$. The DNS analysis by Miller (1959) was performed to analyze the reducing sugar before and after the hydrolysis process, measured using a spectrophotometer with a wavelength of $540 \mathrm{~nm}$. HPLC analysis was used to find lactic acid concentration.

\section{RESULTS AND DISCUSSION}

\section{Effect of the acid-organosolv pretreatment process}

The pretreatment process aimed to open the lignocellulose structure so that cellulose or hemicellulose would be easier to degrade by enzymes. TAPPI Test Method T222 was carried out to investigate the chemical composition of untreated and pretreated SPTW. The result of cellulose, hemicellulose, and lignin content are summarized in Table 2. It showed that SPTW lignin content can be removed from $27.24 \%$ to $19.86 \%$ $(27.09 \%)(w / w)$ and cellulose content can increase from 
$40.10 \%$ to $62.69 \%(56.33 \%)(\mathrm{w} / \mathrm{w})$ after acid-organosolv pretreatment. The decrease in lignin in the SPTW was significant due to the physical structure of the SPTW fiber, which is physically soft. In another study conducted by Mesa et al. (2011), lignin content of up to $17.1 \%(w / w)$ was removed with sugarcane bagasse as a substrate with a different organosolv pretreatment temperature of $185^{\circ} \mathrm{C}$. On the other hand, a study conducted by Brodeur et al. (2016) of the same raw material using $0.5 \%$ (w/w) phosphoric acid solvent in the first stage, then proceed using organic solvents in the form of $50 \% \mathrm{w} / \mathrm{w} \mathrm{N}$-methyl morpholine N-oxide (NMMO), was able to remove lignin by $11.42 \%$. In addition, a study by Sheng et al. (2011) on oil palm empty fruit bunches raw material using $1.63 \%$ sulfuric acid and $65 \%$ organic ethanol solvent at $160^{\circ} \mathrm{C}$ for 78 minutes was able to remove lignin by $80.99 \%$ (w/w).

Figure 1 shows that the X-Ray Diffraction analysis results of the SPTW before and after pretreatment indicate that $\mathrm{I}_{002}$ is a crystalline fraction of cellulose at a maximum diffraction peak intensity of $2 \theta=22.5^{\circ}$, which is the most common form of cellulose found in nature, according to Karapatsia et al. (2017), and $I_{a m}$ is the fraction amorphous cellulose at minimum diffraction peak intensity $2 \theta=18.7^{\circ}$ (Yoshida et al. 2014). Cellulose is a complex biopolymer consisting of amorphous and crystalline cellulose. Enzymes digest the amorphous cellulose more easily before the enzyme becomes slower when digesting more difficult crystalline cellulose (Park et al. 2010). CrI is one of the essential parameters that describe the crystalline content of cellulose per cellulose sample content (Barlianti et al. 2015). Crystalline cellulose has limited accessibility to water and chemical solutions. Chemical destruction occurs in the amorphous phase and the crystalline surface. The composition of crystalline cellulose and amorphous cellulose must be known in order to formulate a mixture of enzymes for the cellulose hydrolysis process.

In the SPTW raw material after acid-organosolv pretreatment, the CrI value increased from $10.90 \%$ to $50.0 \%$ indicating the loss of amorphous compounds from the sample, and the cellulose structure had also been opened, possibly due to the removal of water extractive and hemicellulose remaining in the crystalline cellulose during the acid pretreatment process (Timung et al. 2016).

Figure 2 shows a decrease in mass of the untreated SPTW. Pretreatment is shown from the TGA and DTG curves, where there is a loss of material mass with increasing temperature. Mass loss due to evaporation of moisture content can be seen from temperatures of 35-150 ${ }^{\circ} \mathrm{C}$, whereas for cellulose at temperatures of $225-325{ }^{\circ} \mathrm{C}$. From the TGA and DTG curves of sugar palm residue, it can be seen that there are many stages of mass loss that occur due to the more diverse compositions of sugar palm trunk waste, with fairly balanced values between components. The results obtained are shown in Table 3 , with the reading following the temperature range in Table 1. The chemical composition of untreated SPTW consisted of moisture (11.67\%), hemicellulose $(18.97 \%)$, cellulose $(42.72 \%)$, lignin $(16.10 \%)$, and ash $(10.54 \%)$. The results of this experiment in line with research conducted by Ilyas et al. (2019) was used Arenga pinnata waste as a substrate and Arenga pinnata waste was analyzed with TGA to obtain the chemical composition.

\section{Preliminary study of enzymatic hydrolysis activities}

The enzymatic hydrolysis process was carried out to form reducing sugar from cellulose. The results of the measurements of pure cellulase enzyme activity from $A$. niger and T. reesei are shown in Table 4. From the results of the calculation of the enzyme activity, a calculation was made of the needs of a mixture of cellulase enzymes from $A$. niger and T. reesei. The concentration of enzymes used in the hydrolysis was $1.063 \mathrm{U}$ cellulase enzymes from $A$. niger/1 g enzyme and $1.182 \mathrm{U}$ cellulase enzymes from $T$. reesei/1 g enzymes, each dissolved in $100 \mathrm{~mL}$ of citrate buffer solution $\mathrm{pH}$ 5.5. The hydrolysis process was then conducted with different units (13.29 U, 18.6 U, $20.73 \mathrm{U}$, and $26.58 \mathrm{U}$ ) on the same amount of substrate to find the appropriate number of units, and the needs of the enzyme added.

From Figure 3, it can be seen that the concentration of reducing sugars in the cellulase enzymes of $T$. reese $i$ with various enzyme units obtained the highest reducing sugar concentrations at $18.6 \mathrm{U}$ at $7.046 \mathrm{~g} / \mathrm{L}$, while the reducing sugar concentrations at $13.2 \mathrm{U}, 20.73 \mathrm{U}$, and $26.58 \mathrm{U}$ had values of $4.615 \mathrm{~g} / \mathrm{L}, 6.009 \mathrm{~g} / \mathrm{L}$ and $5.466 \mathrm{~g} / \mathrm{L}$ respectively. It can, therefore, be concluded that the cellulase enzyme unit for $1 \mathrm{~g}$ of SPTW is $18.6 \mathrm{U}$, and the need for mixed enzymes for various combinations of cellulase enzymes from $A$. niger and $T$. reese $i$ with various ratios $(0: 1,1: 0$, $1: 1,1: 2$ and $2: 1$ ) can be calculated.

Table 2. Comparison of chemical composition of untreated SPTW and pretreated SPTW

\begin{tabular}{lcc}
\hline Composition & Untreated SPTW & Pretreated SPTW \\
\hline Cellulose & 40.10 & 62.69 \\
Hemicellulose & 16.50 & 10.44 \\
Lignin & 27.24 & 19.86 \\
\hline
\end{tabular}

Table 3. Chemical composition of the results of the TGA analysis in the untreated SPTW

\begin{tabular}{lc}
\hline Component & Content $(\boldsymbol{\%})$ \\
\hline Moisture & 11.67 \\
Hemicellulose & 18.97 \\
Cellulose & 42.72 \\
Lignin & 16.10 \\
Ash & 10.54 \\
\hline
\end{tabular}

Table 4. Measurement of cellulase enzyme activity from Aspergillus niger and Trichoderma reesei

\begin{tabular}{|c|c|c|c|c|}
\hline \multirow{2}{*}{ Enzyme } & \multicolumn{3}{|c|}{ Absorbance (A) } & \multirow{2}{*}{$\begin{array}{c}\text { Activity } \\
\text { (U/mL } \\
\text { enzyme) }\end{array}$} \\
\hline & $\left(\mathbf{A}_{1}\right)$ & $\left(\mathbf{A}_{2}\right)$ & $\left(A_{1}-A_{2}\right)$ & \\
\hline Cellulase from AN & 1.568 & 0.881 & 0.0687 & 1.063 \\
\hline Cellulase from TR & 0.803 & 0.039 & 0.764 & 1.182 \\
\hline
\end{tabular}

Note: $A_{1}$ : Absorbance of the solution before correction. $A_{2}$ : Absorbance of the solution after correction. Enzyme activity = $\left(A_{1}-A_{2}\right) x$ reducing sugar curve slope 


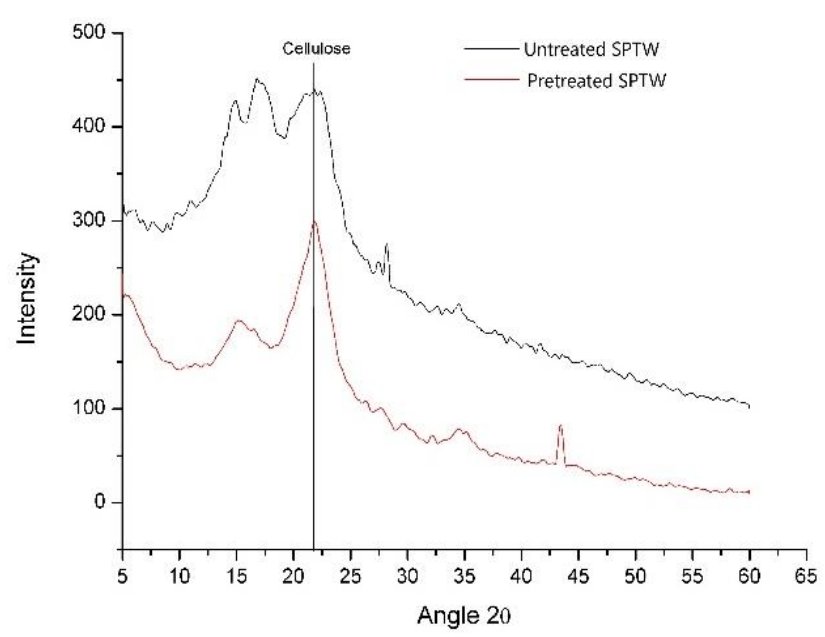

Figure 1. X-Ray Diffraction untreated SPTW and pretreated SPTW analysis results

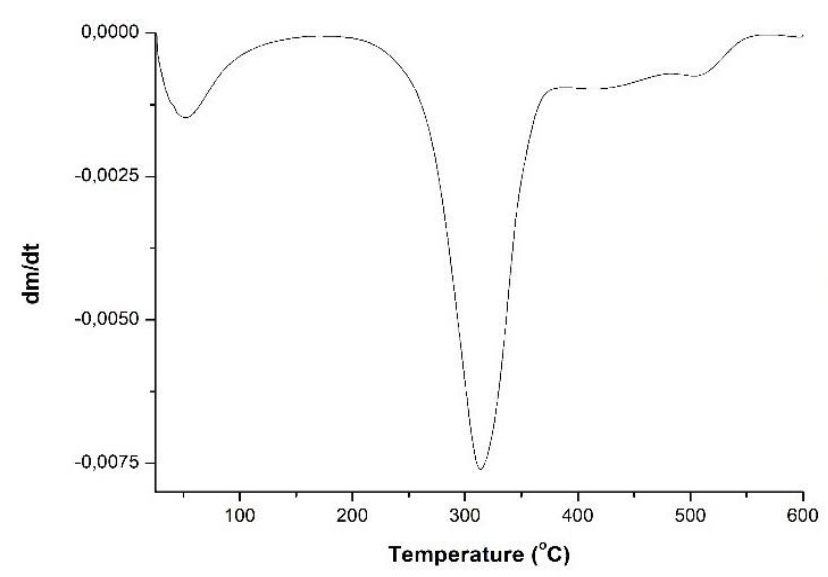

Figure 2. TGA of the untreated SPTW

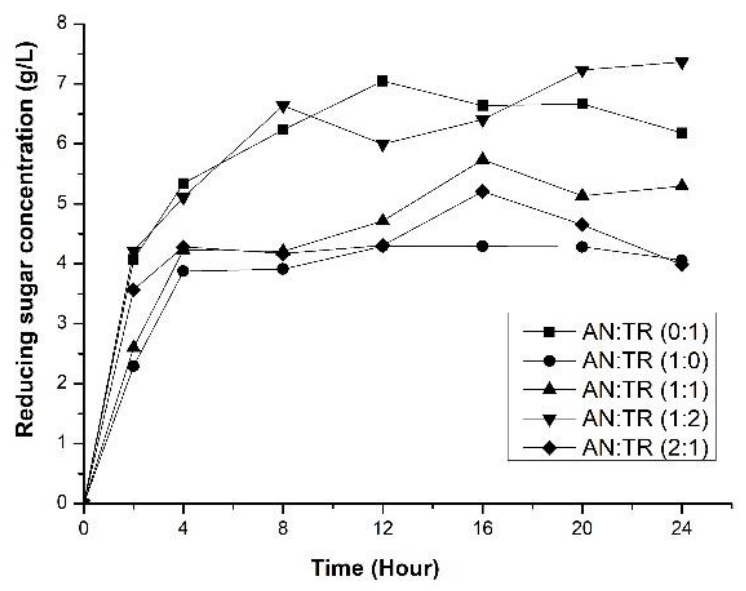

Figure 4. Hydrolyzed reducing sugar concentrations from a combination of cellulase enzymes from AN and TR

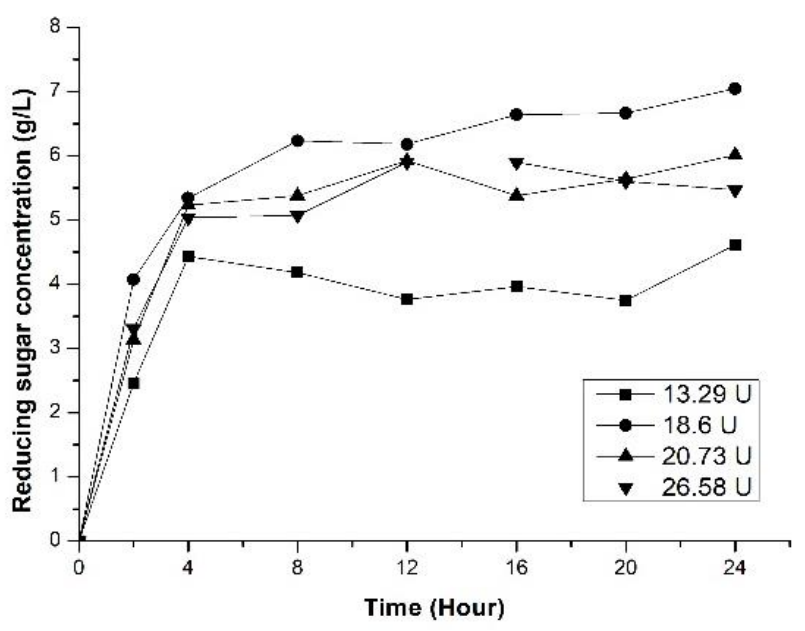

Figure 3. Reducing sugar concentrations with various units in the cellulase enzyme from TR

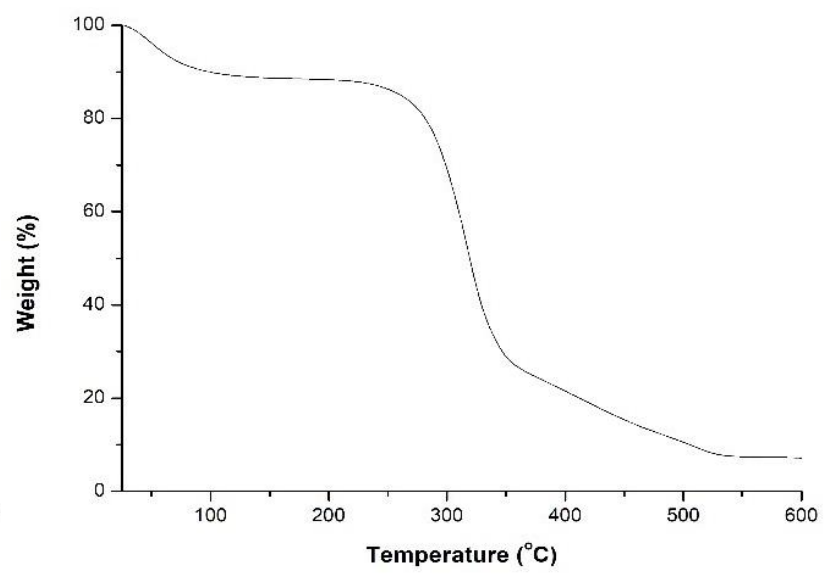

Hydrolysis of sugar palm trunk waste with a combination of pure cellulase enzymes from Aspergillus niger and Trichoderma reesei

In this research, the hydrolysis process was performed with varying mixtures of cellulase enzymes isolated from A. niger and T. reesei, in order to compare the effect of these on the mixture of cellulase enzymes, the variations being AN:TR 0:1, 1:0, 1:1, 1:2 and 2:1. Because Endo-1,4$\beta$-D-glucanase, Exo-1,4- $\beta$-D-glucanase, and 1,4- $\beta$-Dglucosidase act synergistically to convert cellulose to glucose. This enzyme belongs to the group of hydrolases known as cellulases.

From Figure 4, it appears that the value of reducing sugar concentration tends to increase with hydrolysis time. The SPTW hydrolysis using a mixture of cellulase enzymes A. niger (AN) and T. reesei (TR) at the AN:TR ratio of $1: 2$ has the highest reducing sugar concentration value of 7.367 $\mathrm{g} / \mathrm{L}$, compared to cellulase enzymes from A. niger and $T$. 
reesei without the combination, which was $4.060 \mathrm{~g} / \mathrm{L}$ and $6.182 \mathrm{~g} / \mathrm{L}$ respectively.

This is consistent with the study conducted by Hamzah et al. (2019), in which the reducing sugars obtained from immobilized $A$. niger and $T$. reesei without a mixture produced a lower quantity of sugars compared to a combination of the two. AN:TR at a ratio of $1: 2$ is the best combination, with the amount of reducing sugar obtained being $1.02 \mathrm{~g} / \mathrm{L}$. This proves that the synergy of the two cellulase enzymes can increase the production of reducing sugars. The synergistic of cellulase enzyme from A. niger and cellulase enzyme from $T$. reese $i$ was investigated using SPTW as a substrate. The composition of enzymes in cellulase varies based on the microorganisms that produce it. T. reesei produces more endo-1,4- $\beta$-D-glucanase, Exo-1,4- $\beta$ D-glucanase, and 1,4- $\beta$-D-glucosidase (Stockto et al. 1991), while A. niger is known for its ability to produce $\beta$ glucosidase with a much higher yield than the Trichoderma species (Juhász et al. 2003). Therefore, the combination of the two types of cellulase will significantly increase the yield of reducing sugars. Based on the HPLC analysis in the study, hydrolysis using a mixture of cellulase enzymes at an AN:TR ratio of 1:2 has the highest reducing sugar concentration $(16.95 \mathrm{~g} / \mathrm{L})$ than hydrolysis using cellulase enzymes from $T$. reesei $(14.57 \mathrm{~g} / \mathrm{L})$.

\section{Lactic acid fermentation production efficiency with various lactic acid bacteria}

There are two types of lactic acid fermentation metabolism, namely homolactic and heterolactic fermentation. Homolactic fermentation can produce pure produce lactic acid from glucose through the EMP/glycolytic pathway in anaerobic conditions and the PP pathway in aerobic conditions (Bhagavan 2015), while heterolactic fermentation, besides producing lactic acid, also produces ethanol and acetic acid through the PK pathway. One can choose this pathway by selecting the appropriate type of bacteria. Homolactic bacteria are only able to use glucose type, glucose to produce pure lactic acid, while heterolactic bacteria use glucose type, glucose to produce lactic acid and xylose, and arabinose-type reducing sugars to produce ethanol and acetic acid (Cubascano et al. 2018).

In this fermentation process, single microorganisms (Lactobacillus acidophilus, L. casei, L. brevis and L. rhamnosus) and mixed cultures of Lactobacillus acidophilus and L. brevis; L. casei and L. brevis; and $L$. rhamnosus and $L$. brevis were used. Homofermentative bacteria were chosen because they are homolactic lactic acid bacteria capable of purely producing lactic acid via the EMP pathway under anaerobic conditions, with a maximum conversion of lactic acid of 2 moles for 1 mole of glucose (Cubascano et al. 2018). The equation of the fermentation reaction that occurs through the EMP pathway is as follows Eq. (2):

$$
\text { Glucose }+2 \mathrm{Pi}+2 \mathrm{ADP} \rightarrow 2 \mathrm{LA}+2 \mathrm{ATP}+2 \mathrm{H}_{2} \mathrm{O}
$$

The reaction of the fermentation process with added $\mathrm{CaCO}_{3}$ as a neutralizing agent is as follows :

$$
\begin{aligned}
& \mathrm{C}_{6} \mathrm{H}_{12} \mathrm{O}_{6} \rightarrow 2\left(\mathrm{CH}_{3} \mathrm{CHOHCOOH}\right) \\
& \mathrm{C}_{6} \mathrm{H}_{12} \mathrm{O}_{6}+\mathrm{CaCO}_{3} \rightarrow \mathrm{Ca}\left(\mathrm{CH}_{3} \mathrm{CHOHCOO}\right)_{2}+\mathrm{CO}_{2}+\mathrm{H}_{2} \mathrm{O}
\end{aligned}
$$

\section{$\mathrm{CaSO}_{4}$ \\ $\mathrm{Ca}\left(\mathrm{CH}_{3} \mathrm{CHOHCOO}\right)_{2}+\mathrm{H}_{2} \mathrm{SO}_{4} \rightarrow \mathrm{CH}_{3} \mathrm{CHOHCOOH}+$}

Based on the reaction during fermentation process, glucose as a substrate was converted by using microorganisms as lactic acid. Where, $\mathrm{CaCO}_{3}$ was added as a neutralizing agent. Fermentation was conducted for 48 hours at $37^{\circ} \mathrm{C}$ and $\mathrm{pH} 6$. In a study conducted by Panesar et al. (2010), it was stated that an operating temperature of $37^{\circ} \mathrm{C}$ was the optimum temperature for producing lactic acid using Lactobacillus culture. Previous research by Buyukkileci and Harsa (2004) also found that temperatures below $30^{\circ} \mathrm{C}$ and above $40^{\circ} \mathrm{C}$ had a reasonably slow product formation rate. $\mathrm{pH}$ 5.5-6.5 is the optimum $\mathrm{pH}$ for lactic acid fermentation with Lactobacillus culture. In addition, the control of $\mathrm{pH}$ conditions is also a focus in the fermentation process because $\mathrm{pH}$ is one of the main factors affecting lactic acid production through the fermentation process. This is because the catalytic activity of enzymes and the metabolic activity of microorganisms depends on extra cell pH (Mussatto 2008).

During the fermentation process, a DNS analysis was performed to test the reduction of reducing sugars by sampling every 6 hours. The downward trend can be seen in Figure 5. From Figure 5, it can be seen that the reduction in the concentration of reducing sugars between Lactobacillus acidophilus (1.086 g/L), L. brevis (1.067 $\mathrm{g} / \mathrm{L})$ and mixed culture Lactobacillus acidophilus $+L$. brevis $(0.457 \mathrm{~g} / \mathrm{L})$ shows that there is microorganism activity in the fermented medium in the fermentation process, which forms products in the form of lactic acid. The graph shows that the fermentation medium experiences a more drastic reduction in reducing sugar with the microorganism L. rhamnosus + L. brevis. It can be concluded from the results of the study that a mixture of microorganisms can increase lactic acid production and be more efficient. The result of lactic acid concentration using HPLC analyzed is summarized in Table. 5.

Table 5. Data analysis of lactic acid concentration based on HPLC

\begin{tabular}{lc}
\hline Variable microorganism & $\begin{array}{c}\text { Lactic acid } \\
\text { concentration }(\mathbf{g} / \mathbf{L})\end{array}$ \\
\hline L. acidophilus $(L A)$ & 10.422 \\
L. brevis $($ LB $)$ & 15.444 \\
L. casei $($ LC) & 11.093 \\
L. rhamnosus $($ LR $)$ & 15.493 \\
L. acidophilus + L. brevis $(L A B)$ & 17.207 \\
L. casei + L. brevis $($ LCB $)$ & 11.708 \\
L. rhamnosus + L. brevis $($ LRB $)$ & 33.293 \\
\hline
\end{tabular}



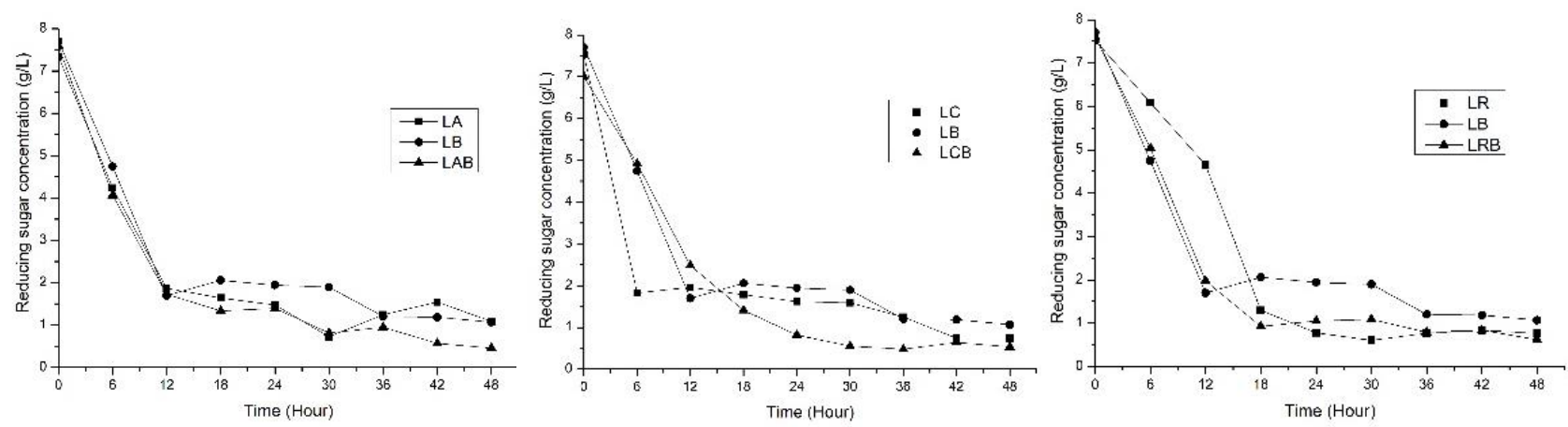

Figure 5. Reduction of the concentration of reducing sugar curves during the fermentation process for 48 hours with a variety of microorganisms

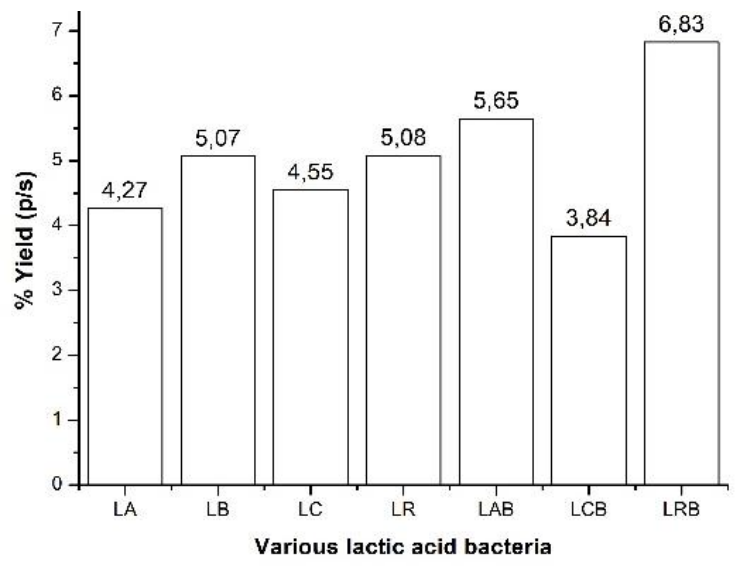

Figure 6. Yield of lactic acid from various lactic acid bacteria

From Figure 6, it can be seen that the yield of lactic acid from various lactic acid bacteria showed that the best result is the mixed culture of L. rhamnosus + L. brevis, with a concentration of lactic acid obtained of $33.293 \mathrm{~g} / \mathrm{L}$ and a yield of $6.83 \%$. Compared with each microorganism L. rhamnosus and L. brevis a lactic acid concentration of $15.493 \mathrm{~g} / \mathrm{L}$ and $15.444 \mathrm{~g} / \mathrm{L}$, respectively. The mechanism of mutual presence of mixed culture can enhance lactic acid concentration because the microorganisms to be effective in consuming substrate. On the other hand, Lactobacillus acidophilus, L. casei, and L. rhamnosus were chosen because they are homofermentative bacteria that can consume hexose sugar and $L$. brevis is heterofermentative bacteria that can convert a limited amount of glucose and xylose to lactic acid (Bushara et al. 2018). Mixed culture or co-cultures of lactic acidproducing microorganisms can increase the efficiency of substrate conversion. Nancib et al. (2009) compared the production of lactic acid from date palm juice with a single culture and a mixture of $L$. casei and Lactobacillus lactis. A lactic acid concentration of $60.3 \mathrm{~g} / \mathrm{L}$ and $96 \%$ glucose utilization efficiency were achieved with a mixture of $L$. casei and L. lactis culture after 19 hours incubation, while the concentrations of lactic acid of $53 \mathrm{~g} / \mathrm{L}$ and $42 \mathrm{~g} / \mathrm{L}$, and respective glucose utilization of $82.2 \%$ and $93.8 \%$, were obtained with a single culture of $L$. casei and L. lactis. Research conducted by Cui et al. (2011) explains that the mixed culture of L. rhamnosus and L. brevis yields lactic acid of $0.70 \mathrm{~g} / \mathrm{g}$, which is around $18.6 \%$ and $29.6 \%$ higher than that of the single culture of L. rhamnosus and $L$. brevis, respectively.

\section{ACKNOWLEDGEMENTS}

The author would like to express gratitude to the Research and Community Service Foundation of Institut Teknologi Sepuluh Nopember (LPPM-ITS), and for the financial support from the Ministry of Research, Technology, and Higher Education of the Republic of Indonesia, with contract number 3/E1/KP.PTNBH/2020

\section{REFERENCES}

Alves R, Oliveira D, Komesu A, Eduardo C, Rossell V. 2018. Challenges and opportunities in lactic acid bioprocess design - from economic to production aspects. Biochem Eng J 133: 219-239.

Andrić P, Meyer A.S, Jensen P.A, Dam-Johansen K. 2010. Reactor design for minimizing product inhibition during enzymatic lignocellulose hydrolysis: I. Significance and mechanism of cellobiose and glucose inhibition on cellulolytic enzymes. Biotechnol Adv 28: 308-324.

Barlianti V, Dahnum D, Hendarsyah H, Abimanyu H. 2015. Effect of alkaline pretreatment on properties of lignocellulosic oil palm waste. Procedia Chem 16: 195-201.

Bhagavan NV, Ha CE. 2015. Essentials of Medical Biochemistry, 2nd ed. Elsevier, Nederland.

Brodeur G, Telotte J, Stickel J.J, Ramakrishnan S. 2016. Bioresource Technology Two-stage dilute-acid and organic-solvent lignocellulosic pretreatment for enhanced bioprocessing. Bioresour Technol 220: 621-628.

Bushara MH, Alkoaik F, Abasaeed A, Fulleros R. 2018. Fermenting Saudi wasted dates by using Lactobacillus casei (ATCC 393), Acidophilus (CICC 6088), and the mixed culture bacteria to produce lactic acid. Open J Appl Sci 8: 150-157.

Buyukkileci AO, Harsa S. 2004. Batch production of L(+) lactic acid from whey by Lactobacillus casei (NRRL B-441). J Chem Technol Biotechnol 97: 1036-1040.

Chaisu K, Charles AL, Guu Y, Yen T, Chiu H, 2014. Optimization lactic acid production from molasses renewable raw material through response surface methodology with Lactobacillus casei M-15. Procedia Soc Behav Sci 8: 194-198.

Cubascano E, González- Fernández C, Ballesteros M, Tomás- Pejó E. 2018. Biotechnological advances in lactic acid production by lactic 
acid bacteria: lignocellulose as novel substrate. Biofuels Bioprod Bioref. DOI: $10.1002 / \mathrm{bbb} .1852$

Cui F, Li Y, Wan C. 2011. Lactic acid production from corn stover using mixed cultures of Lactobacillus rhamnosus and Lactobacillus brevis. Bioresour Technol 102: 1831-1836.

Fenila F, Yogendra S. 2016. Optimal control of enzymatic hydrolysis of lignocellulosic biomass. Resour Technol 2: S96-S104

Hamzah A, Sitompul LL, Putri INF, Soeprijanto, Widjaja A. 2019. Synergistic effect of two type cellulase immobilized on chitosan microparticle as biocatalyst for coconut husk hydrolysis. Indon J Chem 22: 495-502.

Ilyas RA, Sapuan SM, Ibrahim R, Abral H, Ishak MR, Zainudin ES Asrofi M, Atikah MSN, Huzaifah MRM. 2019. Sugar palm (Arenga pinnata (Wurmb.) Merr) cellulosic fiber hierarchy: a comprehensive approach from macro to nanoscale. J Mater Res Technol 8 (3): $2753-$ 2766.

Ismail E, Khaneghah AM, Barba FJ, Saraiva JA, Sant AS, Mohammad S, Hashemi B. 2018. Recent advancements in lactic acid production-a review. Food Res Intl 107: 763-770.

Juhasz T, Kozma K, Szengyel Z, Reczey K. 2003, Production of $\beta$ glucosidase in a mixed culture of Aspergillus niger BKMF 1305 and Trichoderma reesei RUT C30. Food Technol Biotechnol 41 (1): 4953.

Karapatsia A, Pappas I, Penloglou G, Kotrotsiou O, Kiparissides C. 2017. Optimization of dilute acid pretreatment and enzymatic hydrolysis of Phalaris aquatica L. lignocellulosic biomass in batch and fed-batch processes. Bioenerg Res 10: 225-236.

Li Y, Sun Z, Ge X, Zhang J. 2016. Effects of lignin and surfactant on adsorption and hydrolysis of cellulases on cellulose. Biotechnol Biofuels 9: 20. DOI: 10.1186/s13068-016-0434-0.

Loelovich M. 2015. Methods for determinations of the chemical composition of plant biomass. Journal SITA 17 (4): 208-214.

Mesa L, González E, Cara C, Gonzalez M, Castro E, Mussatto SI. 2011. The effect of organosolv pretreatment variables on enzymatic hydrolysis of sugarcane bagasse. Chem Eng J 168: 1157-1162.

Mesa L, González E, Cara C, Ruiz E, Castro E, Mussatto SI. 2010. An approach to optimization of enzymatic hydrolysis from sugarcane bagasse based on organosolv pretreatment. J Chem Technol Biotechnol 85: 1092-1098.
Mille GL. 1959. Use of dinitrosalicylic acid reagent for determination of reducing sugar. Anal Chem 31: 426-428

Mussatto SI, Fernandes M, Mancilha IM, Roberto C. 2008. Effects of medium supplementation and ph control on lactic acid production from brewer' s spent. Grain 40: 437-444.

Nancib N, Nancib A, Boudjelal A, Benslimane C, Blanchard F, Boudrant J. 2001. The effect of supplementation by different nitrogen sources on the production of lactic acid from date juice by Lactobacillus casei subsp. rhamnosus. Bioresourc Technol 78: 149-153

Panesar PS, Kennedy JF, Knill CJ, Kosseva M. 2010. Production of L(+) lactic acid using Lactobacillus casei from whey. Braz Arch Biol Technol 53 (1): 219-226.

Park S, Baker JO, Himmel ME, Parilla PA, Johnson DK. 2010. Cellulose crystallinity index: measurement techniques and their impact on interpreting cellulase performance. Biotechnol Biofuels 3: 10.

Sanyang ML, Sapuan SM, Jawaid M, Ishak MR, Sahari J. 2016. Recent developments in sugar palm (Arenga pinnata) based biocomposites and their potential industrial applications: a review. Renew Sustain Energy Rev 54: 533-549.

Sheng C, Teng H, Teong K, Brosse N, Universite N, Aiguillettes B. 2011. Evaluation and optimization of organosolv pretreatment using combined severity factors and response surface methodology. Biomass Bioenerg 35: 4025-4033.

Sun Y, Cheng J. 2002. Hydrolysis of lignocellulosic materials for ethanol production : a review. Bioresour Technol 83: 1-11.

TAPPI Test Method T222. Acid-Insoluble Lignin in Wood and Pulp

Timung R, Mohan M, Chilukoti B, Sasmal S, Banerjee T, Goud VV. 2015. Optimization of dilute acid and hot water pretreatment of different lignocellulosic biomass: A comparative study. Biomass Bioenerg 81: 9-18.

Wijaya CJ, Saputra SN, Soetaredjo FE, Putro JN, Lin CX, Kurniawan A Ju YH, Ismadji S. 2017. Cellulose nanocrystals from passion fruit peels waste as antibiotic drug carrier. Carbohydr Polym 175: 370-376.

Wildschut J, Smit AT, Reith JH, Huijgen WJJ. 2013. Ethanol-based organosolv fractionation of wheat straw for the production of lignin and enzymatically digestible cellulose. Bioresour Technol 135: 58-66.

Yoshida M, Liu Y, Uchida S, Kawarada K, Ichinose H, Kaneko S, Fukuda K. 2014. Effects of cellulose crystallinity, hemicellulose, and lignin on the enzymatic hydrolysis of Miscanthus sinensis to monosaccharides. Biosci Biotechnol Biochem 72(3): 805-810. 